\title{
SEX DIFFERENCES IN ALCOHOL ATTRIBUTABLE MORTALITY IN POLAND, 2002-2018
}

\author{
RÓŻNICE MIĘDZY KOBIETAMI A MĘŻCZYZNAMI W UMIERALNOŚCI \\ SPOWODOWANEJ SPOŻYCIEM ALKOHOLU W POLSCE W LATACH 2002-2018
}

\author{
Wittgenstein Centre for Demography and Global Human Capital (IIASA, OeAW, UniVie), \\ Vienna Institute of Demography/Austrian Academy of Sciences
}

\begin{abstract}
We study patterns and developments in sex differences in alcohol-attributable mortality (AAM) in Poland over the years 2002-2018. Sex gap and sex-specific mortality patterns according to age, educational level and urbanrural settlements are contrasted with findings for other developed countries.

Premature AAM of the population 20-64 years old is quantified with age-standardized alcohol-attributable mortality rates (AASMR) by sex and selected characteristics. For the age pattern, we study the gender gap in alcohol-attributable crude death rates for 10-year age groups. Data comes from the World Health Organization database or directly from the Polish Central Statistical Office.

In 2002, in Poland, men died 9-times more often than women from causes attributable to alcohol consumption. As a result of faster growth in AASMR among women, the relative sex gap halved between 2002 and 2018. However, this relative change was accompanied by an increase in the absolute gap, resulting from a larger increase in the total number of deaths attributed to alcohol consumption among men than women. Due to the substantially higher alcohol consumption and mortality among men, differences in AAM according to age, education and place of residence, and their changes over the study years, are much more pronounced for men than women.

Polish men and women are characterized by similar patterns and developments of alcohol-attributable mortality in the study years. Different from that observed for other developed countries narrowing the sex gap, we observe in Poland perseverance of male elevated AAM. An important contribution of the study is the evidence that to understand differences between men and women in AAM and their developments, we need to study both relative and absolute sex gaps.
\end{abstract}

Keywords: alcohol-attributable mortality, sex gap in mortality, sex gap in alcohol-attributable mortality, mortality in Poland

\section{STRESZCZENIE}

Celem pracy było opisanie różnic pomiędzy kobietami a mężczyznami w umieralności spowodowanej spożyciem alkoholu w Polsce w latach 2002-2018. Badaniu podlegał ogólny poziom zjawiska, wzorce umieralności według płci oraz wieku, poziomu wykształcenia, miejsca zamieszkania, a także ich zmiany w badanym okresie. Analizowano przedwczesną umieralność spowodowaną spożyciem alkoholu dotyczącą osób w wieku 20-64 lata, która została skwantyfikowana na podstawie standaryzowanych współczynników zgonów oraz współczynników umieralności w 10-letnich grupach wieku. Dane pochodziły z bazy Światowej Organizacji Zdrowia lub bezpośrednio z Głównego Urzędu Statystycznego.

W 2002 r. w Polsce mężczyźni umierali 9-krotnie częściej niż kobiety z przyczyn związanych ze spożyciem alkoholu. W wyniku szybszego wzrostu zgonów odalkoholowych wśród kobiet niż mężczyzn względna różnica między płciami zmniejszyła się o połowę w latach 2002-2018. Tej względnej zmianie towarzyszyło jednak pogłębienie się różnicy w wartościach bezwzględnych, wynikające z większego wzrostu liczby zgonów odalko- 
holowych wśród mężczyzn niż wśród kobiet. Dodatkowo, ze względu na istotnie wyższy poziom spożycia alkoholu i umieralności mężczyzn, różnice w poziomie umieralności odalkoholowej ze względu na wiek, poziom wykształcenia, miejsce zamieszkania oraz ich zmiany w badanym okresie, są znacznie wyższe dla mężczyzn niż dla kobiet. Wzorce umieralności spowodowanej spożyciem alkoholu oraz ich zmiany w badanych latach, były zbliżone dla kobiet i mężczyzn.

W odróżnieniu od obserwowanego w innych krajach rozwiniętych zmniejszania się różnic umieralności odalkoholowej pomiędzy płciami, w Polsce utrzymuje się nadumieralność mężczyzn. Ważnym wkładem badania jest przedstawienie argumentów przemawiających za tym, że dla zrozumienia różnic między mężczyznami a kobietami w zakresie badanego zjawiska i jego rozwoju należy analizować jednocześnie względne jak i bezwzględne różnice między płciami

Słowa kluczowe: umieralność odalkoholowa, różnice między płciami w umieralności, różnice między płciami w umieralności spowodowanej spożyciem alkoholu, umieralność w Polsce

\section{INTRODUCTION}

The magnitude of alcohol consumption, drinking pattern and their consequences are well-known to differ for men and women. The sex patterns of consumption and related mortality are, however, not universal. They vary across socio-economic groups, contextual factors and change over calendar time (1-6). The most significant change is a convergence between sexes in alcohol consumption and related mortality and results mainly from an increased consumption among women, and in particular, by women in younger age groups (7-13). This narrowing of the sex gap in the risk behaviour is already observed among teenagers (14). This shift in the level and drinking patterns are explained by the observation that young women started to use alcohol in the same way as men $(7,15)$, as a result of different aspects of women's growing participation in employment, delayed childbearing (16), but also societal changes towards acceptance of women's alcohol consumption $(2,5,12)$. A shift in gender roles and the definition of masculinity/feminity is also brought forward to explain differences at the population level in the sex gap in alcohol consumption and its consequences between countries, regions and rural versus urban areas $(1,2,17,18)$. On the individual level, drinking patterns, the magnitude of consumption, and their consequences for both sexes depend on the socioeconomic status: More risky consumption and elevated mortality are observed for those with low educational attainment (19-22). However, the educational gradient of alcohol-related health consequences is significantly stronger for men than for women $(20,23)$.

Similar patterns to those observed in other developed countries have been reported for Poland: Polish men consume on average more alcohol, are less likely to be abstinent/very light drinking than women (24-27) and are more likely than women to die from alcohol-related causes (25). However,

\section{WPROWADZENIE}

Poziom spożycia alkoholu, wzorce spożycia oraz ich konsekwencje różnią się w przypadku mężczyzn i kobiet. Wzorce konsumpcji i związane z nimi konsekwencje zdrowotne także nie są uniwersalne. Różnią się one w zależności od grup społeczno-ekonomicznych, miejsca zamieszkania, a także podlegają zmianom w czasie (1-6). Najważniejszą obserwowaną zmianą jest konwergencja między płciami w zakresie spożycia alkoholu oraz związanej z tym umieralności. Zjawisko to jest wynikiem wzrostu spożycia alkoholu wśród kobiet, a szczególnie kobiet w młodszych grupach wieku (713). Zmniejszanie się różnic między płciami w zakresie spożycia alkoholu obserwuje się już wśród młodzieży w wieku szkolnym (14). Zmiany w poziomie i wzorcach spożycia alkoholu wśród kobiet tłumaczy się najczęściej tym, iż młode kobiety zaczęły spożywać alkohol w taki sam sposób jak mężczyźni $(7,15)$, co było wynikiem ich rosnącego udziału na rynku pracy, opóźnionego macierzyństwa (16), ale także wzrostu akceptacji dla spożycia alkoholu przez kobiety $(2,5,12)$. Zmiana ról płciowych i definicji męskości/kobiecości jest również często przywoływana w celu wyjaśnienia różnic pomiędzy krajami, regionami i obszarami wiejskimi/ miejskimi w kształtowaniu się odmiennych wzorców spożycia alkoholu oraz ich konsekwencji zdrowotnych $(1,2,17,18)$. Zjawiska te zależą także od statusu społeczno-ekonomicznego: bardziej ryzykowne spożywanie i wyższą umieralność obserwuje się u osób z niskim poziomem wykształcenia (19-22). Gradient edukacyjny w konsekwencjach zdrowotnych jest znacznie silniejszy w przypadku mężczyzn niż kobiet $(20,23)$.

W latach poprzedzających badanie wzorce zachowań i ich konsekwencje były zbliżone w Polsce do tych obserwowanych w innych krajach rozwiniętych: polscy mężczyźni spożywali średnio większą ilość alkoholu, rzadziej niż kobiety byli abstynentami lub należeli do grupy o bardzo niskim spożyciu (24-27) i częściej niż kobiety umierali z powodu przyczyn związanych ze spożyciem alkoholu (25). O ile jednak poziom wy- 
while the educational level is negatively correlated to the frequency of alcohol consumption among men $(26,28)$, the positive relationship between educational attainment and alcohol consumption was reported for Polish women $(26,28,29)$. Despite the elevated consumption among higher educated women, the opposite pattern was observed for alcohol-related mortality: The protective character of education for women was reflected in a negative, graded relationship between educational attainment and mortality from alcohol poisoning. A similar educational pattern of alcohol-related mortality was observed for men but of higher magnitude (26). In addition, Polish women who lived in central/urban settings consumed significantly larger amounts of alcohol than women in rural locations (about 50\% more in 2002). The opposite was true for men (20\% lower consumption). While for Polish men, the difference between urban and rural areas was small, women in urban settlements were characterized by twice as high mortality due to alcohol poisoning as those living in the rural areas (26).

To our knowledge, the discussed above study of Wojtyniak et al. (26) is the only comprehensive analysis of the sex gap in alcohol-related mortality in Poland. It focuses on the first 13 years of market transition. This article aims to update these analyses to the next two decades and draw a comprehensive picture concerning the sex gap in alcohol-related mortality in Poland and its trends over this period. This study has a descriptive character: We discuss differences between men and women in the gradient of alcohol-attributable mortality according to age, educational attainment, urban/rural place of residence and changes in the pattern over the study years. Similar to the period directly following the collapse of the iron curtain, the study years are characterized by a rapid increase in the officially recorded alcohol sales and the self-reported consumption per capita of both sexes (Fig. I). The start year of the analysis also marked a decrease in the price of spirits due to a $30 \%$ lowering of the excise tax in January 2003 (30). The drop in the excise price resulted in an immediate increase in economic accessibility of spirits (32), increase in consumption and alcohol-related health consequences (32). According to Zatoński et al. $(33,34)$, the drop in the price of alcohol in 2002 itself resulted in the observed steady increase in alcohol consumption and alcohol-related mortality in the next two decades. The excise tax on spirits was then raised back but never reached the pre-2002 level. In the study period, the most important changes were a rise of the excise tax on spirits by $9 \%$ in 2009 and by $15 \%$ in 2014 (35). The official sales grew from less than $7 \mathrm{~L}$ in 2002 to $9 \mathrm{~L}$ in 2006 and $10 \mathrm{~L}$ per capita in 2018 (Fig. I). An kształcenia jest ujemnie skorelowany $\mathrm{z}$ częstością spożywania alkoholu wśród mężczyzn $(26,28)$, o tyle w przypadku polskich kobiet stwierdzono dodatnią korelację (26, 28-29). Pomimo wyższej konsumpcji wśród kobiet z wyższym wykształceniem, w przypadku umieralności z powodu zatruć alkoholem zaobserwowano odwrotną zależność: ochronny charakter wykształcenia znalazł odzwierciedlenie w ujemnej zależności między poziomem wykształcenia a umieralnością z powodu zatrucia alkoholem. Ten gradient edukacyjny obserwowano również w przypadku polskich mężczyzn (26). Ponadto Polki mieszkające w miastach spożywały istotnie większe ilości alkoholu niż kobiety mieszkające na wsi (o około 50\% więcej w 2002 r.). W przypadku mężczyzn odnotowano odwrotną zależność (o $20 \%$ niższe spożycie). O ile w przypadku polskich mężczyzn różnice pomiędzy umieralnością odalkoholową w miastach i na wsi były niewielkie, o tyle kobiety w miastach charakteryzowała dwukrotnie wyższa umieralność z powodu zatruć alkoholem niż kobiety mieszkające na wsi (26).

Zgodnie z naszą wiedzą, omawiane powyżej badanie Wojtyniaka i współautorów (26) jest jedyną kompleksową analizą różnic w umieralności związanej ze spożyciem alkoholu w Polsce ze względu na płeć. Badanie to koncentruje się tylko na pierwszych 13 latach transformacji rynkowej. Celem niniejszej pracy jest uaktualnienie tych analiz do następnych dwóch dekad i nakreślenie całościowego obrazu różnic między płciami w umieralności spowodowanej spożyciem alkoholu w Polsce. Poniższe badanie ma charakter wyłącznie opisowy. Omawiamy różnice między kobietami i mężczyznami w umieralności spowodowanej spożyciem alkoholu w zależności od wieku, poziomu wykształcenia, miejsca zamieszkania, a także ogólne tendencje i zmiany badanych wzorców na przestrzeni lat 2002-2018. Podobnie jak w okresie bezpośrednio po upadku żelaznej kurtyny, badane lata charakteryzują się szybkim wzrostem oficjalnie rejestrowanej sprzedaży alkoholu oraz deklarowanego spożycia per capita dla obu płci ( Ryc. I). W styczniu 2003 r, w związku z obniżeniem o $30 \%$ podatku akcyzowego, nastąpił znaczący spadek cen alkoholi wysokoprocentowych (30), który spowodowal natychmiastowy wzrost ich dostępności ekonomicznej (32), zwiększenie konsumpcji i intensyfikację konsekwencji zdrowotnych związanych ze spożyciem alkoholu (32). Według Zatońskiego i współautorów $(33,34)$, spadek cen alkoholu w 2002 r. był bezpośrednio odpowiedzialny za obserwowany w następnych dwóch dekadach stały wzrost spożycia alkoholu i związanej z tym umieralności. W badanych latach akcyza na wyroby spirytusowe została ponownie podwyższona, jednak nie osiągnęła poziomu sprzed 2002 roku. Najważniejszymi zmianami było podniesienie akcyzy o 9\% w 2009 roku i o $15 \%$ w 2014 roku (35). W analizowanym okresie oficjalna sprzedaż zwiększyła się z niespełna 7 litrów 
increase in the total volume of the alcohol officially sold was accompanied by a shifting composition of sales: A rise in the consumption of beer and spirits and a decrease in the consumption of wine (36). While in 2008-13 the prevalence of beer and spirits was higher among men, the opposite was true for wine consumption (27). Over the study years, growth in self-reported consumption was more prominent for men (from 12.3 to $15.2 \mathrm{~L}$ of pure alcohol per capita between 2000 and 2016) than for women (from 6.4 to $7.6 \mathrm{~L}$ ). However, the increase of consumption over the study period was likely of similar magnitude for both sexes. This is because the growth in the official sales was higher than the corresponding increase in the reported consumption, and it is a well-known phenomenon that women systematically underreport their consumption to a greater extent than men (37). Also, a rapid increase in the alcohol consumption of Polish women would be an expected consequence of the societal change observed over the study period: the further postponement of childbearing $(38,39)$, shifts in educational attainment (40) and an increase in the tolerance towards women's alcohol consumption (41). We also expect that the rise in the alcohol consumption among Polish women in w 2002 roku do 9 litrów w 2006 roku i 10 litrów per capita w 2018 roku (Ryc. I). Wzrostowi łącznej sprzedaży oficjalnej alkoholu towarzyszyły zmiany w strukturze sprzedaży: wzrost spożycia piwa i napojów spirytusowych oraz spadek spożycia wina (36). W latach 2008-13 odsetek konsumentów piwa i napojów spirytusowych był wyższy wśród mężczyzn, a wina - wśród kobiet (27). W badanych latach wzrost deklarowanego spożycia był bardziej znaczący w przypadku mężczyzn (z 12,3 do 15,2 litra czystego alkoholu per capita w latach 2000-2016) niż w przypadku kobiet (z 6,4 do 7,6 litra). Jest jednak prawdopodobne, że wzrost spożycia był zbliżony wielkością dla obu płci. Po pierwsze, wzrost oficjalnej sprzedaży był wyższy niż odpowiadający mu wzrost deklarowanej konsumpcji. Po drugie, dobrze znanym zjawiskiem jest to, iż kobiety systematycznie zaniżają swoją konsumpcję w większym stopniu niż mężczyźni (37). Ponadto, opierając się na doświadczeniach innych krajów rozwiniętych, gwałtowny wzrost spożycia alkoholu przez polskie kobiety jest oczekiwaną konsekwencją zmian społecznych obserwowanych w badanym okresie: dalszego odkładania macierzyństwa $(38,39)$, wzrostu wykształcenia $(40)$ oraz zwiększającej się tolerancji wobec spożycia alkoholu przez kobiety (41). W związku z tym, podążając za wzorcami

Figure I. Registered alcohol consumption in liters of pure alcohol per capita in Poland, 2000- 2018. Alcohol consumption in liters of pure alcohol per capita by sex in Poland according to the survey data

Rycina I. Oficjalnie rejestrowane, średnie spożycie alkoholu na jednego mieszkańca w Polsce w litrach 100\% czystego alkoholu, 2000-2018. Spożycie alkoholu w litrach 100\% czystego alkoholu na jednego mieszkańca według płci, wyniki badań ankietowych.

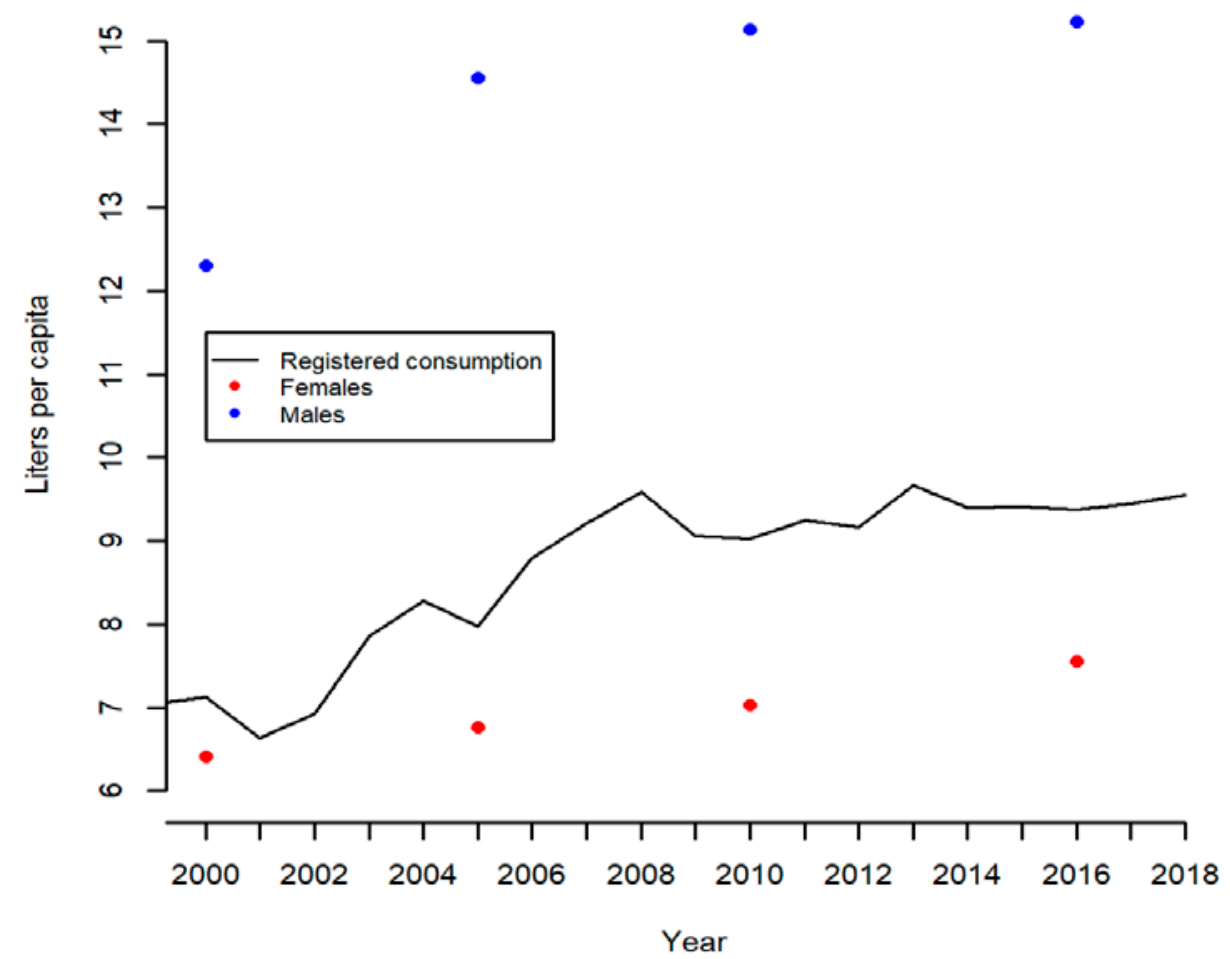

Source: Registered data from the State Agency for the Prevention of Alcohol Problems (36); Survey data on alcohol consumption from Griswold (53) 
the study years resulted in a narrowing of the sex gap in alcohol-related mortality and, following the patterns observed in other developed countries, the differences in alcohol-related mortality between subgroups of the population would become more similar for both sexes.

\section{DATA AND METHODS}

We analyze patterns and trends in alcoholattributable mortality (AAM) for men and women in 2002-2018 according to age, educational level, and the urbanization level of the place of residence. The sex gap is studied both in absolute and relative terms.

We focus on premature adult mortality, defined as deaths occurring between age 20 and 64 years, as the alcohol-related problems have the highest impact on mortality in these age groups $(41,42)$. AAM is defined in this study according to its narrow definition of deaths wholly attributable to alcohol consumption after Rehm et al. (42). The list of causes, together with their corresponding ICD-10 codes, are presented in Table I.

AAM is quantified with age-standardized alcohol-attributable mortality rates (AASMR) by sex and the selected characteristics. The standard population is that of Poland in 2018. We study the gender gap in alcohol-attributable crude death rates (AACDR) for 10-year age groups. Population by the educational attainment, according to the ISCED-11 groups (0-2 - low; 3-4-medium; 5-8 - high level), was estimated by applying data on the share of population by sex, age groups, and educational attainment to the corresponding population counts. Confidence intervals for the rates were estimated for $95 \%$ confidence intervals following Rothman et al. (46) and the National Institute of Cancer (47) for calculating confidence intervals for ratios of rates.

Death counts and corresponding population by sex, age in 5-year groups and the selected characteristics come from the World Health Organization online database (43) or directly from the Polish Central Statistical Office, based on the population registry. Share of the population by sex, age groups, and educational attainment was obtained from the Eurostat online database (44).

\section{RESULTS}

For both sexes, we observe an increase in alcoholattributable mortality in Poland over the years 20022018, with faster growth for women than men (Fig. II). Altogether, between 2002 and 2018, the premature AASMR increased by $70 \%$ for men and more than tripled for women (increase by $230 \%$ ). The largest obserwowanymi w innych krajach rozwiniętych, należy oczekiwać, iż w badanych latach gwałtowny wzrost spożycia alkoholu wśród polskich kobiet spowodował zmniejszenie różnicy między płciami w umieralności odalkoholowej. Ponadto, można przypuszczać, że wzorce umieralności dla obu płci będące wynikiem spożycia alkoholu w wybranych podgrupach społeczno-ekonomicznych będą się upodabniać.

\section{MATERIAŁ I METODY}

W badaniu analizowano wzorce i trendy umieralności mężczyzn i kobiet ze względu na przyczyny zgonów związane bezpośrednio ze spożyciem alkoholu w latach 2002-2018 w zależności od wieku, poziomu wykształcenia i stopnia urbanizacji miejsca zamieszkania. Różnice między płciami badano zarówno w ujęciu bezwzględnym, jak i względnym. Analiza koncentrowała się na przedwczesnej umieralności osób dorosłych, zdefiniowanej jako zgony występujące pomiędzy 20 a 64 rokiem życia, ze względu na to, iż to w tych grupach wieku problemy zdrowotne będące wynikiem spożycia alkoholu mają największy wpływ na umieralność $(41,42)$. Umieralność związana z spożyciem alkoholu w niniejszym badaniu została zdefiniowana zgodnie $\mathrm{z}$ wąską definicją zgonów $\mathrm{w}$ całości przypisywanych negatywnym konsekwencjom spożycia alkoholu za Rehmem i in. (42). Listę przyczyn wraz z odpowiadającymi im kodami ICD-10 przedstawiono w Tabeli I.

Umieralność badana była na podstawie standaryzowanych współczynników zgonów związanych ze spożyciem alkoholu według płci i wybranych cech. Populację standardową stanowiła populacja Polski w 2018 roku. Analizie podlegały także różnice między płciami w wartościach surowych współczynników zgonów dla 10-letnich grup wieku. Liczbę ludności według poziomu wykształcenia, zgodnie z grupami ISCED-11 (0-2 - niskie; 3-4 - średnie; 5-8 - wyższe), oszacowano poprzez zastosowanie dostępnych danych o udziale ludności według płci, grup wieku i poziomu wykształcenia do odpowiadających im danych o liczbie ludności. Przedziały ufności (95\%) dla standaryzowanych współczynników umieralności oszacowano zgodnie z wytycznymi Rothmana i in. (46). Przedziały ufności (95\%) dla odsetka współczynników wyznaczone zostały według wytycznych National Institute of Cancer (47).

Liczba zgonów oraz ludność według płci, wieku (w 5-letnich grupach) oraz według wybranych charakterystyk pochodzą z internetowej bazy danych Światowej Organizacji Zdrowia (43) lub z danych Głównego Urzędu Statystycznego na podstawie prowadzonej ewidencji ludności. Proporcje ludności według płci, grup wieku i poziomu wykształcenia uzyskane zostały $\mathrm{z}$ bazy internetowej Eurostat (44). 
Table I. Disease conditions for adult mortality, which are by definition alcohol-attributable. Number and percentage of all alcohol-attributable deaths for each disease condition for Polish men and women aged 20-64 years, 2002-2018.

Tabela I. Przyczyny zgonów osób dorosłych z definicji związane ze spożyciem alkoholu. Liczba i odsetek wszystkich zgonów dla każdej przyczyny dla polskich mężczyzn i kobiet w wieku 20-64 lat, 2002-2018.

\begin{tabular}{|c|l|c|c|c|c|}
\hline \multirow{2}{*}{$\begin{array}{c}\text { ICD-10 } \\
\text { Code }\end{array}$} & & \multicolumn{2}{|c|}{ Men } & \multicolumn{2}{c|}{ Women } \\
\cline { 2 - 5 } & & Deaths & Percent & Deaths & Percent \\
\hline E24.4 & Alcohol-induced pseudo-Cushing's syndrome & 0 & 0.0 & 0 & 0.0 \\
\hline F10 & Mental and behavioral disorders due to use of alcohol & 22540 & 27.5 & 3246 & 19.2 \\
\hline G31.2 & Degeneration of nervous system due to alcohol & 294 & 0.4 & 56 & 0.3 \\
\hline G62.1 & Alcoholic polyneuropathy & 28 & 0.0 & 10 & 0.1 \\
\hline G72.1 & Alcoholic myopathy & 6 & 0.0 & 0 & 0.0 \\
\hline I42.6 & Alcoholic cardiomyopathy & 2843 & 3.5 & 273 & 1.6 \\
\hline K29.2 & Alcoholic gastritis & 65 & 0.1 & 3 & 0.0 \\
\hline K70 & Alcoholic liver disease & 32769 & 40.0 & 10072 & 59.5 \\
\hline K85.2 & Alcohol-induced acute pancreatitis & 185 & 0.2 & 30 & 0.2 \\
\hline K86.0 & Alcohol-induced chronic pancreatitis & 611 & 0.7 & 88 & 0.5 \\
\hline R78.0 & Finding of alcohol in blood & 0 & 0.0 & 0 & 0.0 \\
\hline T51 & Toxic effect of alcohol & 0 & 0.0 & 0 & 0.0 \\
\hline Q86.0 & Fetal alcohol syndrome (dysmorphic) & 0 & 0.0 & 0 & 0.0 \\
\hline X45 & Accidental poisoning by and exposure to alcohol & 15753 & 19.2 & 2215 & 13.1 \\
\hline X65 & Intentional self-poisoning by and exposure to alcohol & 2496 & 3.0 & 308 & 1.8 \\
\hline Y15 & Poisoning by and exposure to alcohol, undetermined intent & 4308 & 5.3 & 613 & 3.6 \\
\hline Y90 & Evidence of alcohol involvement determined by blood alcohol & 0 & 0.0 & 0 & 0.0 \\
\hline & & 81898 & 100 & 16914 & 100 \\
\hline So & & 0 & 0 \\
\hline
\end{tabular}

Source: Rehm et al. (25, p.36); Author's estimations, data from WHO (44), Eurostat (45) and Polish Central Statistical Office (52)

increase in the rates occurred in the first decade of study for both sexes: A rise by $70 \%$ for men and $180 \%$ for women between 2002 and 2011. As a result of a faster rise in mortality caused by alcohol consumption among females than males, the relative sex gap halved in the study period, from men's rate being almost 9-times higher than that of women in 2002 to be only 4,5 higher in 2018. However, it should be noted that over this period, an increase in the absolute number of alcohol-attributable deaths was greater among men than women. As a result, the absolute sex gap in mortality caused by alcohol consumption increased from the difference of 24 to that of 36 extra deaths per 100,0000 in 2018 for men above those of women.

For both sexes, the premature AAM has a significant age gradient (Table II): The older the age group, the higher the level of AACDR. This results from the fact that most alcohol-related causes of death are degenerative diseases, and the damage due to alcohol consumption accumulates over the life course. Similarly, due to an overall increase in the AAM, we observe that the age gradient becomes steeper for both sexes in the study years. As a result, the older the age group, the larger the absolute difference in AACDR between men and women and the higher the

\section{WYNIKI}

W latach 2002-2018 obserwowano wzrost umieralności związanej z konsumpcją alkoholu dla obu płci (Ryc. II). Przy czym wzrost ten był szybszy dla kobiet niż mężczyzn. Ogółem w latach 2002-2018 przedwczesna umieralność bezpośrednio związana ze spożyciem alkoholu wzrosła o 70\% dla mężczyzn i ponad trzykrotnie dla kobiet (przyrost o 230\%). Najsilniejszy przyrost dla obu płci wystąpił w pierwszej dekadzie badania (2002-2011) - o 70\% dla mężczyzn i 180\% dla kobiet. W wyniku szybszego wzrostu umieralności spowodowanej spożyciem alkoholu wśród kobiet niż mężczyzn, stosunek standaryzowanych współczynników zgonów dla obu płci zmniejszył się o połowę w badanym okresie - od prawie 9-krotnie wyższego współczynnika dla mężczyzn niż dla kobiet w 2002 r. do zaledwie 4,5 wyższego w 2018 r. Należy jednak zauważyć, że w tym okresie wzrost liczby zgonów związanych ze spożyciem alkoholu był wyższy wśród mężczyzn niż kobiet. W rezultacie bezwzględna różnica między płciami w umieralności spowodowanej spożyciem alkoholu zwiększyła się z 24 do 36 dodatkowych zgonów na 100 tys. osób dla mężczyzn powyżej liczby zgonów kobiet. 
Figure II. Standardized Alcohol Attributable Mortality Rates (AASMR), Sex-gap in AASMR and Change in AASMR in Poland, 2002-2018

Rycina II. Standaryzowane współczynniki zgonów spowodowanych spożyciem alkoholu według płci (AASMR), stosunek współczynnika mężczyzn do współczynnika kobiet oraz ich trendy w latach 2002-2018 w Polsce
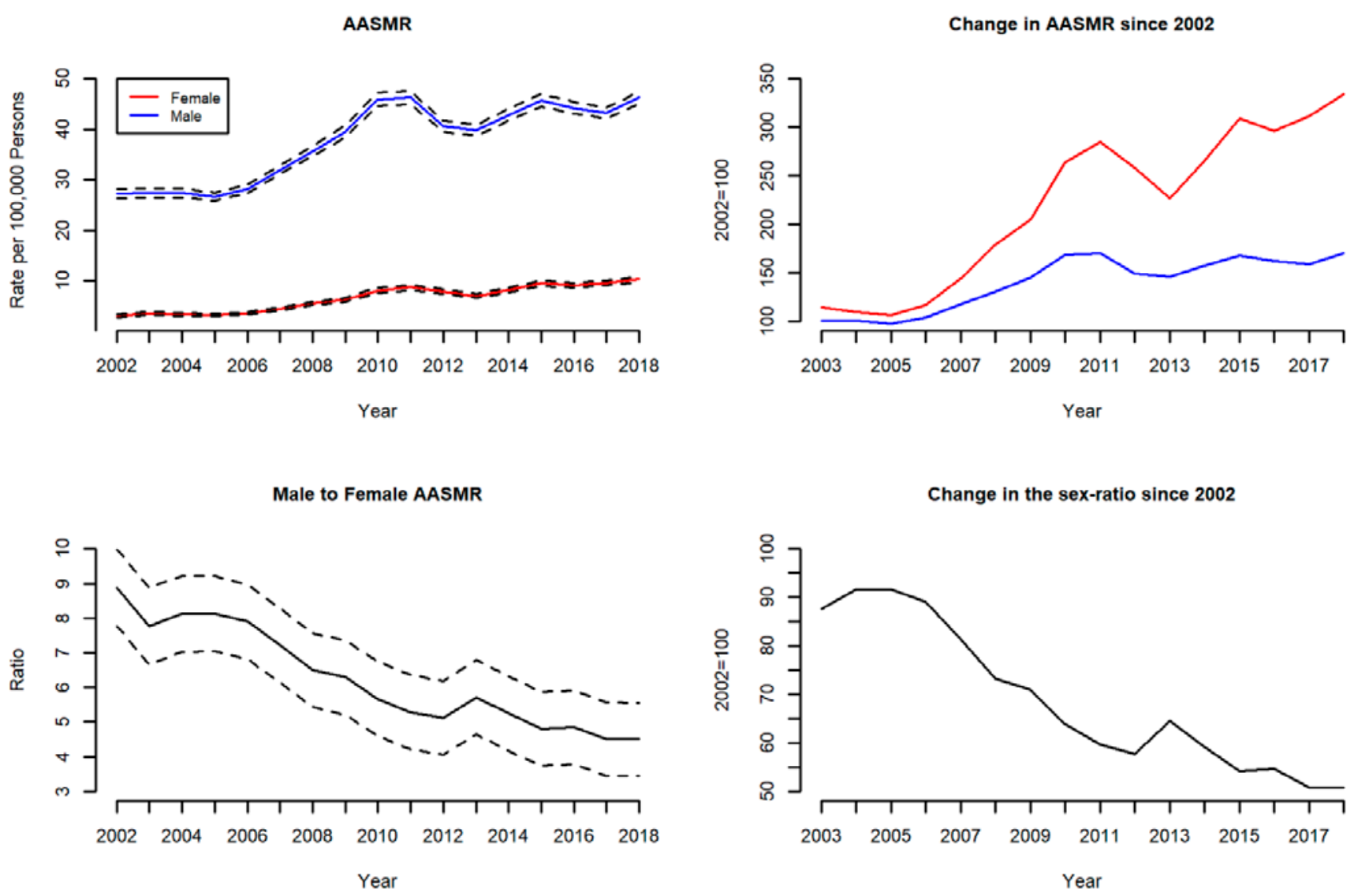

Source: Author's estimations, data from World Health Organization Mortality Database (44)

increase in the sex gap over calendar time. However, no significant age gradient could be observed in AACDR for those above 29 years of age. This result means that the accumulation of the damage of alcohol consumption over the life course is similar for men and women. Only for the youngest age group, 20-29 years, the relative disadvantage of men is significantly higher than in the remaining, older age groups. Contrary to expected, the youngest age group is characterized by the smallest decrease in the relative sex gap over the years $2002-2018$ (by $27 \%$, compared to $51-53 \%$ for older age-groups, numbers derived from Table II but not shown in the Tables). These results differ from findings for other countries, where the growing similarity in alcohol consumption and its damaging effect for men and women for every younger cohort was reflected in a stronger narrowing of the sex gap in the AACDR for the youngest age groups.

Polish men and women are characterized by a significant educational gradient of premature AAM. As the pattern is similar for both sexes, no significant educational gradient is observed for the relative sex gap. However, the results differ when the gap is studied in absolute terms: Due to an overall higher
Dla obu płci, umieralność spowodowana spożyciem alkoholu wykazuje istotny gradient ze względu na wiek (Tab. II): im starsza grupa wieku, tym wyższy współczynnik zgonów. Związane jest to $\mathrm{z}$ faktem, iż większość odalkoholowych przyczyn zgonów to choroby zwyrodnieniowe, gdzie szkody wynikające z konsumpcji alkoholu kumulują się w ciągu życia. Podobnie w badanym okresie można zaobserwować wzrost gradientu umieralności odalkoholowej według wieku dla obu płci. W rezultacie, im starsza grupa wieku, tym większa bezwzględna różnica $\mathrm{w}$ umieralności między mężczyznami i kobietami i tym większy wzrost różnicy między płciami w tym okresie. Natomiast dla względnego stosunku współczynników zgonów spowodowanej spożyciem alkoholu dla obu płci, oraz jego zmian w badanym okresie, nie zaobserwowano istotnego gradientu według wieku. Wynik ten oznacza, że proces kumulowania się szkód wynikających ze spożycia alkoholu w ciągu życia jest podobny dla kobiet i mężczyzn. Wbrew naszym oczekiwaniom, w najmłodszej grupie wieku (20-29 lat) względna nadumieralność mężczyzn jest istotnie wyższa. W badanych latach, ta najmłodsza grupa wieku charakteryzuje się także najniższym spadkiem względnej różnicy między płciami w latach 2002-2018 (o 27\%, 
ةํํㅇ 응

$\stackrel{0}{\square}$

흔 这

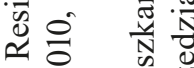

पू

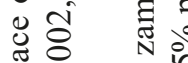

类

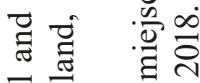

वे

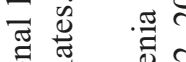

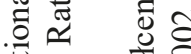

牙

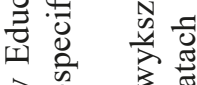

है 容

的

类

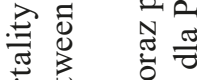

힐

원

苛高 吾

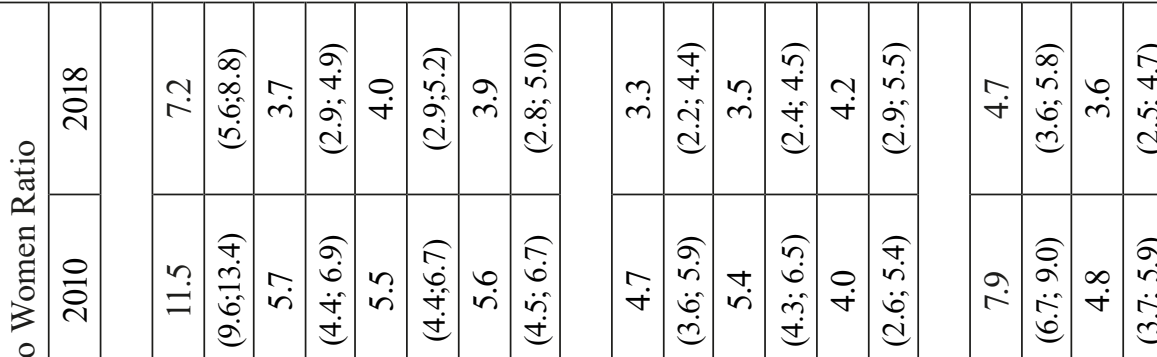

竞

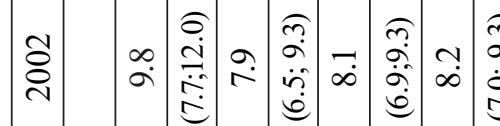

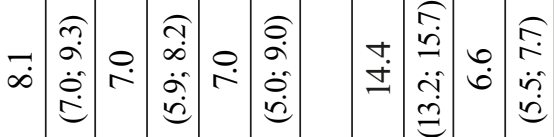

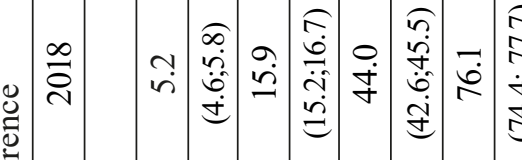

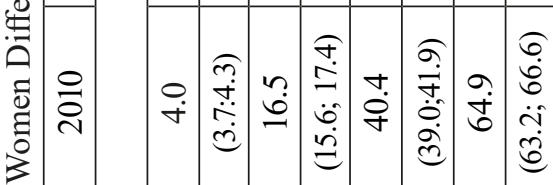

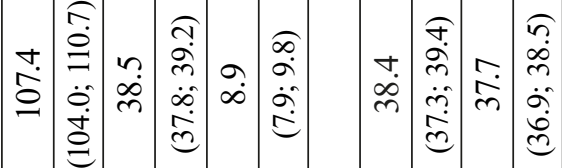

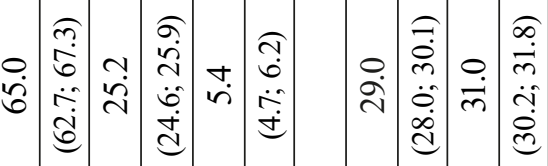

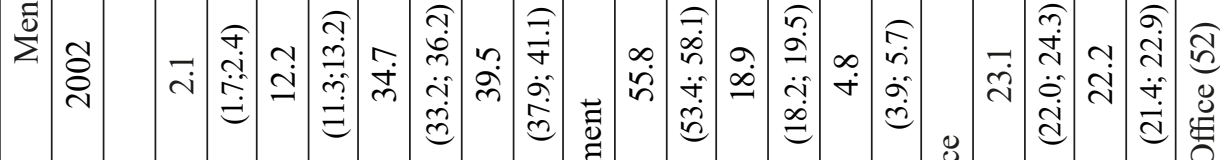

¿

递实

《。

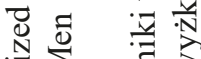

记

苋

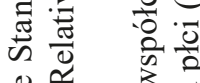

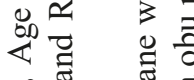

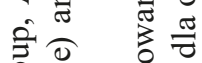

ㅎํ월

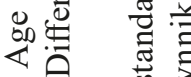

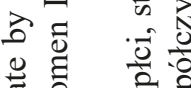

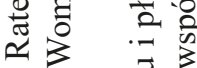

ㄴ)

可 $\overline{0}$ ह

$\sum^{5} \sum^{\infty}$

2 o

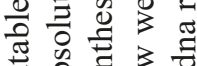

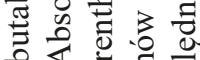

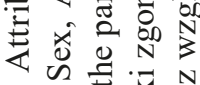

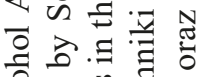

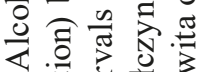

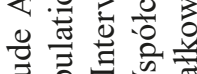

등

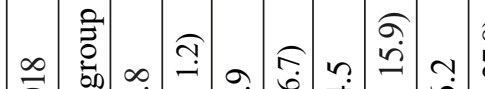

.

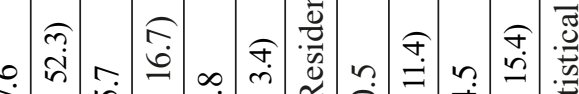

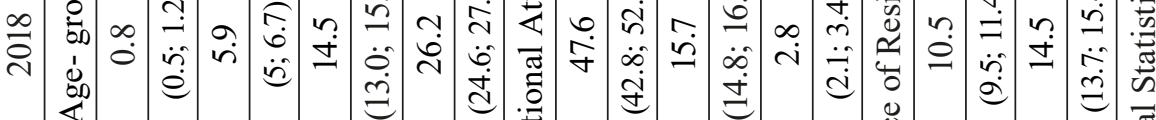

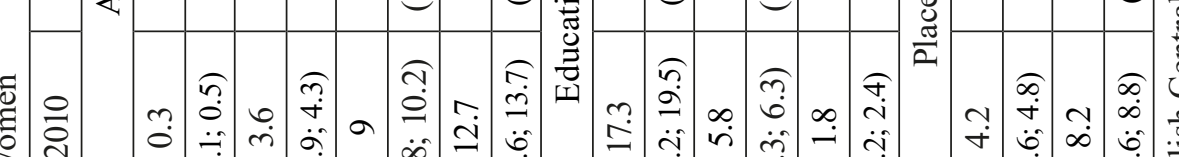

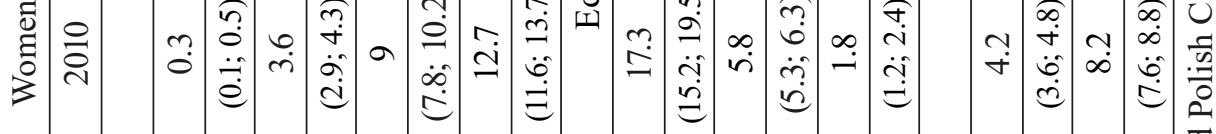

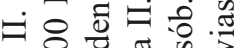

0 응 $\frac{\pi}{0}$ \&

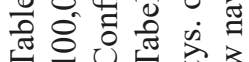

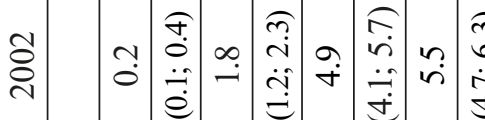

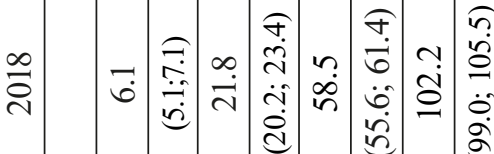

$\stackrel{\text { eี }}{\sum} \stackrel{0}{2}$

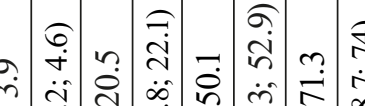

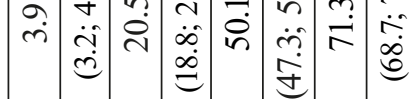

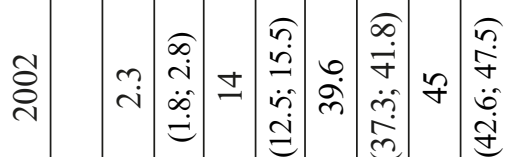

\begin{tabular}{|c|c|}
\hline 仓े & \begin{tabular}{l} 
f̀ \\
$\vdots$ \\
\multirow{y}{*}{}
\end{tabular} \\
\hline
\end{tabular}

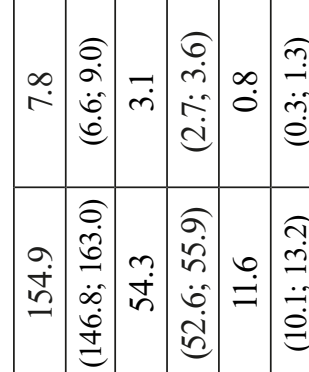

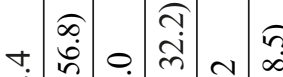

ป

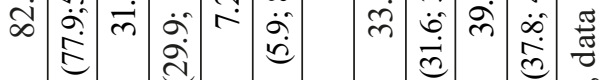

กิ નิ

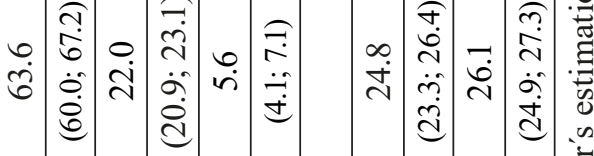

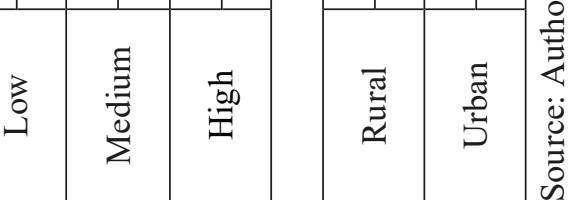


alcohol-attributable men's mortality, the differences in the AASMR between educational groups are more prominent for men. The importance of educational attainment for AAM is additionally emphasized by the fact that, despite the overall higher level of mortality among men, highly educated men have lower AASMR than low educated women. Moreover, in 2018, highly educated men had lower AASMR than women with medium educational attainment.

Over the study years, we observe an increase in AAM in all educational groups and for both sexes. The lower the educational level, the larger the increase. In relative terms, these developments were of higher importance for women's mortality: Altogether, between 2002 and 2018, we observe an over 6-fold increase in AASMR for women with low educational attainment, a 5-fold increase for women with medium educational levels, and 3.5-fold growth for those with high educational attainment. The corresponding numbers for men were: 2.4, 2.5 and 2.1 (numbers not shown in the Tables). As a result of these changes, the lower the educational level, the higher the decrease in the relative sex gap in the AASMR. Again, when men's and women's AASMR are compared in absolute numbers, the opposite pattern is revealed: The lower the educational level, the higher the increase in the absolute sex gap as a result. In absolute numbers, the described above pattern of growth in mortality across the educational groups is more substantial for men than women.

The urbanization level of the place of residence is of minor importance for alcohol-related mortality than age or educational attainment. For both sexes, AASMR is only slightly higher in urban areas than in rural areas. Over the study period, these urbanrural differences become insignificant for men due to a higher increase in mortality in the rural areas and remain at a similar, stable level for women. In relative terms, the excess AAM of men is higher in rural areas than in urban areas, but we also observe a more substantial convergence in the rates between the sexes in the rural areas. In absolute terms, however, no significant differences between the sexes in the AASMR are observed, and the observed change is of similar magnitude.

\section{SUMMARY AND DISCUSSION}

This article describes the sex gap in alcoholattributable mortality in Poland and compares it to that reported for other developed countries. We focus on the overall level and dynamics of AAMR of Polish men and women in the years 2002-2018, together with differences between sexes according to education, agegroups, and between urban and rural areas. wobec spadku o 51-53\% dla starszych grup wieku, statystyki wyznaczone na podstawie danych w Tabeli II, nieprzedstawione w tabelach). Wyniki te różnią się od ustaleń dla innych krajów, w których rosnące podobieństwo spożycia alkoholu i jego szkodliwego działania dla mężczyzn i kobiet wśród każdej młodszej kohorty znajdowało odzwierciedlenie w silniejszym zmniejszaniu się różnicy między płciami we współczynnikach umieralności spowodowanej spożyciem alkoholu dla najmłodszych grup wieku.

Zarówno wśród kobiet jak i mężczyzn w Polsce obserwuje się istotny gradient umieralności odalkoholwej ze względu na poziom wykształcenia. W rezultacie zbliżonego rozkładu według poziomu wykształcenia dla obu płci nie obserwuje się istotnego gradientu edukacyjnego dla względnej różnicy we współczynnikach. Jednak wyniki te różnią się, gdy różnica ta jest badana w wartościach bezwzględnych: ze względu na ogólnie wyższą umieralność mężczyzn związaną ze spożyciem alkoholu, różnice we współczynnikach pomiędzy grupami wykształcenia są bardziej znaczące w przypadku mężczyzn. Wpływ wykształcenia na umieralność odalkoholową dodatkowo podkreśla fakt, że pomimo ogólnie wyższej umieralności wśród mężczyzn, mężczyźni z wysokim poziomem wykształcenia mają niższe współczynniki umieralności niż kobiety z niskim wykształceniem. Co więcej, w 2018 r. współczynniki zgonów dla mężczyzn z wyższym wykształceniem były niższe niż dla kobiet o średnim poziomie wykształcenia.

W badanym okresie we wszystkich grupach wykształcenia i dla obu płci można zaobserwować wzrost standaryzowanych współczynników zgonów ze względu na spożycie alkoholu. Im niższy poziom wykształcenia, tym wzrost ten był większy. W ujęciu względnym zmiany te miały większe znaczenie dla umieralności kobiet: łącznie w latach 2002-2018 obserwujemy ponad 6-krotny wzrost umieralności związanej ze spożyciem alkoholu dla kobiet o niskim poziomie wykształcenia, 5-krotny wzrost dla kobiet o średnim poziomie wykształcenia oraz 3,5-krotny wzrost dla kobiet o wysokim poziomie wykształcenia. Odpowiednie wartości dla mężczyzn wynosiły: 2,4; 2,5 i 2,1 (wyznaczone na podstawie danych z Tab. II, nieprzedstawione w tabelach). W wyniku tych zmian, im niższy poziom wykształcenia, tym większy spadek względnej różnicy między płciami w badanych współczynnikach. Ponownie, gdy współczynniki dla mężczyzn i kobiet są porównywane w wielkościach bezwzględnych, ujawnia się odwrotna prawidłowość im niższy poziom wykształcenia, tym większy wzrost bezwzględnej różnicy między płciami we współczynnikach. Wynika to z faktu, iż w liczbach bezwzględnych opisane powyżej różnice we wzroście umieralności odalkoholowej w poszczególnych grupach wy- 
Over the study years, we observe an increase in alcohol consumption of men and women that resulted in an increase in AAM for both sexes. The relative sex gap in AAMR halved in the study years. However, this result cannot be interpreted as the expected convergence in AAM, as the absolute sex gap indicated the opposite developments: In total numbers, an increase in the consumption of alcohol and mortality was of a higher magnitude for men than women.

For both sexes, the premature AAM has a significant age gradient, indicating accumulation of the damage of alcohol consumption over the life course. As the overall absolute sex gap increases in the study period, the age gradient for the difference between men and women in AACDR becomes steeper. Contrary to what was expected, no convergence between AACDR of men and women, particularly in the youngest age groups, is observed. Also, the relative sex gap in AACDR has no significant age gradient for the older age groups, nor convergence among the younger age groups in Poland is observed. However, similar to findings for other countries and patterns reported for Poland in the previous decades, we observe a graded relationship between educational level and AAMR with a protective effect of education of a larger extend for Polish men than women. The relative and absolute sex gap developments were in the opposite direction: the lower the educational level, the higher the increase in the absolute sex gap and the higher the decrease in the relative gap. Compared to educational attainment or age, the effect of the contextual variable of the urbanization level of the place of residence is of minor importance for the phenomenon under study.

To summarize, most of the results of this study correspond to those reported by Wojtyniak et al. (26) for Poland in 1986-2002. However, the patterns and their developments over the calendar years are different from our expectations based on the literature review of findings for other countries and theoretical explanations for differences in men's and women's drinking patterns and sex-specific behavioral changes in alcohol consumption and its consequences. The differences between the sexes in the pattern of AAM according to the study characteristics was present when studied in absolute but not in relative terms. Also, we expected a convergence in male and female alcoholattributable mortality, particularly among younger cohorts, those with higher educational attainment and living in urban areas. As a result of greater increase in the number of alcohol-attributable deaths among men and despite the growing mortality among women, this convergence was not observed.

A potential limitation to this study comes from the well-known problems with the accuracy of reporting causes of death in Poland. First, Poland is known for kształcenia są bardziej znaczące dla mężczyzn niż dla kobiet.

Stopień urbanizacji miejsca zamieszkania ma mniejsze znaczenie dla poziomu umieralności spowodowanej spożyciem alkoholu niż wiek czy poziom wykształcenia. Dla obu płci przedwczesna umieralność odalkoholowa jest tylko nieznacznie wyższa w miastach niż na wsi. W badanym okresie, ze względu na większy wzrost umieralności na obszarach wiejskich, różnice między miastem a wsią stają się nieistotne dla mężczyzn i pozostają na podobnym, stabilnym poziomie w przypadku kobiet. W ujęciu względnym, nadumieralność mężczyzn w stosunku do kobiet spowodowana spożyciem alkoholu jest wyższa na obszarach wiejskich niż miejskich. Jednocześnie w badanym okresie można zaobserwować szybszą konwergencję współczynników dla obu płci na obszarach wiejskich niż miejskich. Natomiast, w przypadku absolutnych różnic we współczynnikach dla obu płci, ich wielkość jest zbliżona w obszarach miejskich i wiejskich, a także zmiany w obserwowanym okresie są podobne w obu typach miejsca zamieszkania.

\section{PODSUMOWANIE I DYSKUSJA}

W niniejszym artykule opisane zostały różnice pomiędzy kobietami a mężczyznami w umieralności spowodowanej spożyciem alkoholu w Polsce oraz porównane zostały z wynikami dla innych krajów rozwiniętych. Badanie koncentruje się na ogólnym poziomie oraz zmianach we współczynnikach w latach 20022018, z uwzględnieniem różnic między płciami w zależności od poziomu wykształcenia, wieku, a także pomiędzy obszarami miejskimi i wiejskimi.

$\mathrm{W}$ badanych latach obserwowano wzrost spożycia alkoholu zarówno przez mężczyzn, jak i kobiety, a także będący tego wynikiem wzrost umieralności odalkoholowej dla obu płci. Pomimo, iż w badanych latach stosunek standaryzowanego współczynnika zgonów odalkoholowych dla mężczyzn do współczynnika dla kobiet zmniejszył się o połowę, wynik ten nie może być interpretowany jako konwergencja w poziomie umieralności. Wynika to $\mathrm{z}$ faktu, iż bezwzgledna różnica we współczynnikach wskazywała raczej na wzrost dysproporcji - w wartościach bezwzględnych wzrost spożycia alkoholu i umieralność były na wyższym poziomie dla mężczyzn niż dla kobiet.

Zarówno w przypadku mężczyzn, jak i kobiet, umieralność odalkoholowa wykazuje istotny statystycznie gradient ze względu na wiek, co jest wynikiem kumulacji szkód wynikających z konsumpcji alkoholu w ciągu całego życia. Wraz ze wzrostem bezwzględnej dysproporcji pomiędzy płciami w okresie objętym badaniem, również gradient ze względu na wiek dla badanej różnicy staje się bardziej stromy. Wbrew naszym 
low-quality cause-of-death data due to the frequent assignment of deaths to unknown and ill-defined causes and other so-called 'garbage' codes, defined as causes of death that are not useful in analyses of public health and mortality (46-51). Also, the stigma attached to an alcohol-attributable cause of death may result in underreporting such events in death certificates. This effect is likely to depend on sex, age, level of education, and residence of an individual and hence potentially introduce bias into the associations studied in the paper.

An important contribution of this descriptive study is the evidence that to understand the patterns and developments in alcohol-related mortality between men and women, the analyses of the sex gap should be performed simultaneously in absolute and relative terms.

Acknowledgements: The author would like to express her gratitude to the two anonymous reviewers for their constructive comments.

This work was supported by the European Research Council within the EU Framework Programme for Research and Innovation Horizon 2020, ERC Grant Agreement No. 725187 (LETHE).

\section{REFERENCES}

1. Erol A, Karpyak VM. Sex and gender-related differences in alcohol use and its consequences: Contemporary knowledge and future research considerations. Drug Alcohol Dep 2015;156:1-13.

2. Holmila M, Raitasalo K. Gender differences in drinking: why do they still exist? Add 2005; 100 (12):1763-1769.

3. McCartney G, Mahmood L, Leyland AH, et al. Contribution of smoking-related and alcoholrelated deaths to the gender gap in mortality: evidence from 30 European countries. Tob Control 2011; 20 (2):166-168.

4. Probst C, Roerecke M, Behrendt S, et al. Gender differences in socio-economic inequality of alcohol-attributable mortality: A systematic review and meta-analysis. Drug Alcohol Rev 2015;34 (3):267-277.

5. Wilsnack RW, Vogeltanz ND, Wilsnack SC, et al. Gender differences in alcohol consumption and adverse drinking consequences: cross-cultural patterns. Add 2000; 95(2):251-265.

6. Wilsnack RW, Wilsnack SC, Kristjanson AF, et al. Gender and alcohol consumption: patterns from the multinational Genacis project. Add 2009; 104 (9):1487-1500.

7. Bloomfield $\mathrm{K}, \mathrm{Gmel} \mathrm{G}$, Neve R, et al. Investigating gender convergence in alcohol consumption in Finland, Germany, the Netherlands, and oczekiwaniom, opartym na obserwacjach tego zjawiska w innych krajach rozwiniętych, w badanym okresie nie nastąpiła w Polsce konwergencja pomiędzy badanymi współczynnikami dla kobiet i mężczyzn w młodszych grupach wieku. Podobnie jak w przypadku innych krajów i wzorców odnotowanych dla Polski w poprzednich dekadach, w badanych latach obserwowano istotny gradient umieralności odalkoholowej ze względu na poziom wykształcenia, przy czym efekt ochronny wykształcenia dla umieralności jest wyższy dla polskich mężczyzn niż kobiet. Jednak zmiany we względnej i bezwzględnej różnicy płci według poziomu wykształcenia miały w latach 2002-2018 przeciwny kierunek: im niższy poziom wykształcenia, tym większy wzrost bezwzględnej różnicy między płciami, a jednocześnie większy spadek względnej różnicy. W porównaniu z poziomem wykształcenia czy wiekiem, wpływ zmiennej kontekstualnej, jaką jest poziom urbanizacji miejsca zamieszkania, miał nieistotne znaczenie dla badanego zjawiska.

Podsumowując, większość wyników obecnego badania odpowiada wynikom dla Polski w latach 19862002 przedstawionym przez Wojtyniaka i in. (26). Wzorce umieralności obu płci w Polsce ze względu na spożycie alkoholu, oraz ich przemiany w latach 2002-2018, odbiegają od naszych oczekiwań opartych na przeglądzie literatury, teoretycznych rozważaniach dotyczących różnic we wzorcach spożycia alkoholu przez mężczyzn i kobiety oraz obserwowanych zmianach w tych zachowaniach. Różnice między płciami we wzorcu AAM zgodnie z charakterystyką badania były obecne w ujęciu bezwzględnym, ale nie względnym. Spodziewaliśmy się również zbieżności umieralności mężczyzn i kobiet związanych z alkoholem, szczególnie wśród młodszych kohort, osób z wyższym wykształceniem i mieszkających w miastach. W wyniku większego wzrostu liczby zgonów spowodowanych alkoholem wśród mężczyzn i pomimo rosnącej umieralności wśród kobiet, zbieżności tej nie zaobserwowano.

Potencjalne ograniczenie badania wynika z problemów z dokładnością raportowania przyczyn zgonów w Polsce. Po pierwsze, Polska jest znana z niskiej jakości danych dotyczących przyczyn zgonów ze względu na częste przypisywanie zgonów do przyczyn nieznanych i niedokładnie określonych oraz innych tak zwanych ,śmieciowych” kodów, zdefiniowanych jako przyczyny, które nie są przydatne $\mathrm{w}$ analizach zdrowia publicznego i umieralności (46-51). Ponadto, jest to prawdopodobne, iż stygmatyzacja zgonów spowodowanych przez spożycie alkoholu może powodować, iż liczba zgonów z tych przyczyn jest często nie podawana $\mathrm{w}$ aktach zgonów i w rezultacie istotnie niedoszacowana. Dodatkowo, efekt ten może zależeć od płci, wieku, poziomu wykształcenia i miejsca za- 
Switzerland: a repeated survey analysis. Subst Abus 2001;22 (1):39-53.

8. Holmila M, Raitasalo K. Gender differences in drinking: why do they still exist? Add 2005;100 (12):1763-1769.

9. Keyes KM, Li G, Hasin DS. Birth cohort effects and gender differences in alcohol epidemiology: a review and synthesis. Alcohol Clin Exp Res 2011; 35(12):2101-2112.

10. Kuntsche E, Kuntsche S, Knibbe R, et al. Cultural and gender convergence in adolescent drunkenness: evidence from 23 European and North American countries. Arch Pediat Adol Med 2011;165(2):152-158.

11. Seedat S, Scott KM, Angermeyer MC, et al. Crossnational associations between gender and mental disorders in the world health organization world mental health surveys. Arch Gen Psychiat 2009; 66 (7):785-795.

12. Slade T, Chapman C, Swift W, et al. Birth cohort trends in the global epidemiology of alcohol use and alcohol- related harms in men and women: systematic review and metaregression. BMJ Open 2006; 6 (10).

13. Roche AM, Deehan A. Women's alcohol consumption: emerging patterns, problems and public health implications. Drug Alcohol Rev 2002;21(2):169-178.

14. Mokinaro S, Vincente J, Benedetti E, et al. ESPAD Report 2019: Results From European School Survey Project on Alcohol and Other Drugs; 2020.

15. Alati R, Betts KS, Williams GM, et al. Generational increase in young women's drinking: a prospective analysis of mother-daughter dyads. JAMA Psychiat 2014; 71 (8):952- 957.

16. Kerr-Corrêa F, Igami TZ, Hiroce V, et al. Patterns of alcohol use between genders: A cross-cultural evaluation. J Affec Disorders 2007;102(1-3):265- 275.

17. Kuntsche S, Gmel G, Knibbe RA, et al. Gender and cultural diffrences in the association between family roles, social stratiffication, and alcohol use: a European cross-cultural analysis. Alcohol Alcoholism 2006;41(suppl_1):i37-i46.

18. Rahav G, Wilsnack R, Bloomfield $\mathrm{K}$, et al. The influence of societal level factors on men's and women's alcohol consumption and alcohol problems. Alcohol Alcoholism 2006;41:i47-i55.

19. Jones L, Bates G, McCoy E, et al. Relationship between alcohol-attributable disease and socio-economic status, and the role of alcohol consumption in this relationship: a systematic review and meta- analysis. BMC public health 2005;15 (1):400.

20. Mackenbach JP, Kulhánová I, Bopp M, et al. Inequalities in alcohol-related mortality in 17 European countries: a retrospective analysis of mortality registers. PLoS Med 2015;12 (12). mieszkania danej osoby i w rezultacie mieć wpływ na opisane powyżej wyniki.

Istotnym wkładem powyższego badania opisowego jest wykazanie, iż aby zrozumieć różnice pomiędzy płciami we wzorcach i zmianach w umieralności spowodowanej spożyciem alkoholu, zjawisko powinno podlegać jednoczesnej analizie w kategoriach zarówno względnych, jak i bezwzględnych.

Podziękowania: Autorka pragnie wyrazić swoją wdzięczność dwóm anonimowym recenzentom za ich bardzo pomocne komentarze.

Praca została wsparta przez European Research Council w ramach Programu Ramowego Badań i Innowacji UE Horizon 2020, ERC Grant Agreement No. 725187 (LETHE).

21. Probst C, Roerecke M, Behrendt S, et al. Socioeconomic differences in alcohol-attributable mortality compared with all-cause mortality: a systematic review and meta-analysis. Int $\mathrm{J}$ Epidemiol 2014;43 (4):1314-1327.

22. Simons-Morton BG, Farhat T, Ter Bogt TF, et al. Gender specific trends in alcohol use: crosscultural comparisons from 1998 to 2006 in 24 countries and regions. Int J Public Health 2009; 54 (2):199-208.

23. Östergren $\mathrm{O}$, Martikainen $\mathrm{P}$, Lundberg $\mathrm{O}$. The contribution of alcohol consumption and smoking to educational inequalities in life expectancy among Swedish men and women during 19912008. Int J Public Health 2018; 63(1):41-48.

24. Popova S, Rehm J, Patra J, et al. Comparing alcohol consumption in Central and Eastern Europe to other European countries. Alcohol Alcoholism 2007;42(5):465-473.

25. Rehm J, Sułkowska U, Mańczuk M, et al. Alcohol accounts for a high proportion of premature mortality in Central and Eastern Europe. Int $\mathrm{J}$ Epidemiol 2007;36:458-467.

26. Wojtyniak B, Moskalewicz J, Stokwiszewski J, et al. Gender specific mortality associated with alcohol consumption in Poland in transition. Add 2005;100:1779-1789.

27. Moskalewicz J, Room R, Thom B. Comparative monitoring of alcohol epidemiology across the EU. Baseline Assessment and Suggestions for Future Action. Synthesis Report.Warsaw, PARPAThe State Agency for Prevention of Alcohol Related Problems; 2016.

28. Stelmach W, Kaczmarczyk-Chalas K, Bielecki W, et al. The impact of income, education and health on lifestyle in a large urban population of Poland (Cindi Programme). Int J Occup Med Environ Health 2004;17(3):393-401. 
29. Skrzypczak M, Szwed A, Pawlińska-Chmara R, et al. Body mass index, waist to hip ratio and waist/ height in adult polish women in relation to their education, place of residence, smoking and alcohol consumption. Homo 2008;59(4):329-342.

30. Zmarzlowski K, Orlowski A. Podatek akcyzowy zwyrobów alkoholowych jako źródło finansowania budżetu państwa w latach 1999-2012. Roczniki Naukowe Stowarzyszenia Ekonomistów Rolnictwa i Agrobiznesu 2014;16(2).

31. Moskalewicz J, Sierosławski J. Dostępność ekonomiczna napojów spirytusowych a szkody zdrowotne. Alkohol Narkom 2005; 18(4):41-8.

32. Moskalewicz J, Wieczorek S. Dostępność, konsumpcja alkoholu i konsekwencje picia alkoholu trzy dekady doświadczeń. Alkohol Narkom 2009;22:305-337.

33. Zatoński WA, Zatoński M, Janik-Koncewicz K, et al. Alcohol-related deaths in Poland during a period of weakening alcohol control measures. JAMA 2021; 325(11): 1108-1109.

34. Zatoński WA, Sulkowska U, Zatoński MZ, et al. Alcohol taxation and premature mortality in Europe. The Lancet 2015;385(9974):1181.

35. Rola K. Wpływ podatku akcyzowego na konsumpcjęalkoholi.PraceNaukowe Uniwersytetu Ekonomicznego we Wrocławiu 2016; 451:374-384.

36. State Agency for the Prevention of Alcohol Problems. Statistics, available at http://www.parpa. pl/index.php/badania-i-informacje-statystyczne/ statystyki. Retrieved July 2020.

37. Stockwell T, Zhao J, Greenfield T, et al. Estimating under- and over-reporting of drinking in national surveys of alcohol consumption: identification of consistent biases across four English-speaking countries. Add 2016;111(7):1203-1213.

38. Tymicki K, Zeman K, Holzer-Żelażewska D. Cohort fertility of Polish women, 1945-2015: the context of postponement and recuperation. Studia Demograficzne 2018; 2(174):5-23.

39. Kotowska IE. Uwagi o urodzeniach i niskiej dzietności w Polsce oraz polityce rodzinnej wspierającej prokreację. Studia Demograficzne 2020;2(176):11-29.

40. Inglot-Brzęk E. Przemiany demograficzne a rozwój szkolnictwa wyższego w Polsce. Nierówności społeczne a wzrost gospodarczy 2012; 26:216-229.

41. Podstawski R, Wesołowska E, Choszcz D, et al. Drinking behaviours and alcohol preferences of female and male students at a Polish university in 2000-2016. Drug-Educ Prev Policy 2019; 26(3):280-286.

42. Grigoriev P, Jasilionis D, Klüsener $\mathrm{S}$, et al. Spatial patterns of male alcohol-related mortality in Belarus, Lithuania, Poland and Russia. Drug Alcohol Rev 2020; doi:10.1111/dar.13037
43. Rehm J, Baliunas D, Borges GL, et al. The relation between different dimensions of alcohol consumption and burden of disease: An overview. Add 2010;105:817-843.

44. WHO. World Health Organization Mortality Database. Available at: https://www.who.int/ healthinfo/statistics/mortality_rawdata/en/ (accessed July 2020).

45. Eurostat. Eurostat database. Available at: https:// ec.europa.eu/eurostat/data/database (accessed June 2020).

46. Rothman KJ, Greenland S, Lash TL. Modern epidemiology, 3rd edn. Philadelphia: Lippincott Williams \& Wilkins, 2008.

47. National Institute of Cancer. Rate algorithms. Available at https://seer.cancer.gov/seerstat/ WebHelp/Rate_Algorithms.htm (accessed July 2020)

48. Fihel A, Muszyńska MM, Wróblewska W. Umieralność z przyczyn nieznanych i niedokładnie określonych oraz jej trwałe zróżnicowanie terytorialne w Polsce. Studia Demogr 2014;165:83102.

49. Jędrychowski W, Mróz E, Wiernikowski A, et al. Trafność wyboru przez lekarza wyjściowej przyczyny zgonu i kodowania danych $\mathrm{z}$ kart zgonów. Przegl Epidemiol 2001;55:313-322.

50. Wojtyniak B, Jankowski K, Zdrojewski T, et al. Regional differences in determining cardiovascular diseases as the cause of death in Poland: Time for change. Kardiol Pol 2012;70:695-701.

51. Fihel A, Muszyńska-Spielauer MM. Using multiple cause of death information to eliminate garbage codes. Dem Res 2021;45: 345-360.

52. Polish Central Statistical Office. Cause of death individual record database prepared for this study 2020.

53. Griswold M. Data for alcohol use and burden for 195 countries and territories, 1990-2016: a systematic analysis for the global burden of disease study 2016, 2018; mendeley data, v6.

Received: 15.11.2020

Accepted for publication: 20.07.2021

Otrzymano: 15.11.2021 r.

Zaakceptowano do publikacji: 20.07.2021 r.

\section{Address for correspondence: \\ Adres do korespondencji:}

Magdalena Muszynska-Spielauer

Vienna Institute of Demography

Austrian Academy of Sciences,

Vordere Zollamtsstraße 3,

1030 Vienna, Austria;

email: Magdalena.Muszynska@oeaw.ac.at 